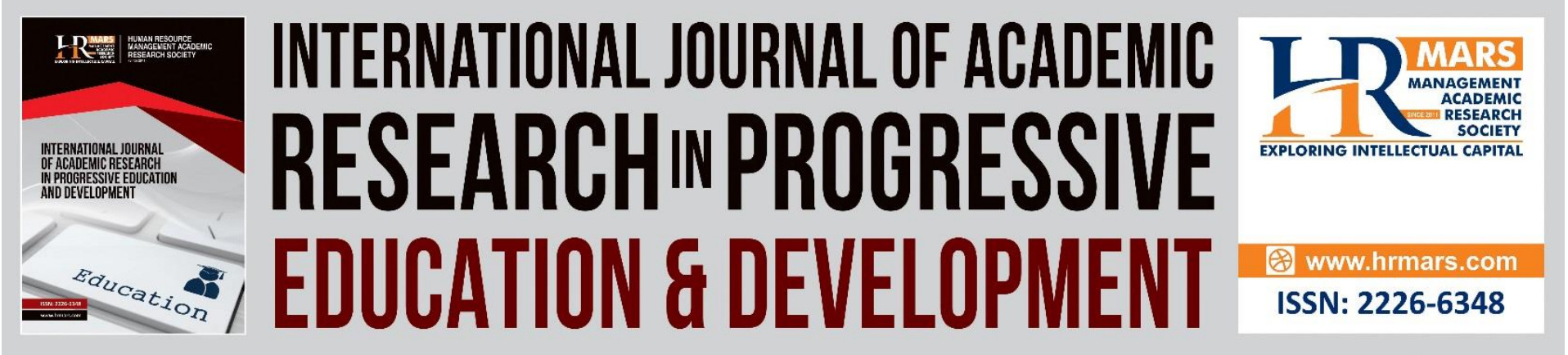

\title{
The Acceptance of Women as Academicians and Mothers When Working from Home (WFH) Becomes A Future Practice: A Preliminary Study
}

Nur Idayu Badrolhisam, Siti Norashikin Bashirun, Nurhafizah Mohd Zolkapli, Nor Maslia Rasli Samudin

To Link this Article: http://dx.doi.org/10.6007/IJARPED/v10-i3/11242

DOI:10.6007/IJARPED/v10-i3/11242

Received: 09 June 2021, Revised: 13 July 2021, Accepted: 30 July 2021

Published Online: 23 August 2021

In-Text Citation: (Badrolhisam et al., 2021)

To Cite this Article: Badrolhisam, N. I., Bashirun, S. N., Zolkapli, N. M., \& Samudin, N. M. R. (2021). The Acceptance of Women as Academicians and Mothers When Working from Home (WFH) Becomes A Future Practice: A Preliminary Study. International Journal of Academic Research in Progressive Education and Development, 10(3), 809-821.

Copyright: (c) 2021 The Author(s)

Published by Human Resource Management Academic Research Society (www.hrmars.com)

This article is published under the Creative Commons Attribution (CC BY 4.0) license. Anyone may reproduce, distribute, translate and create derivative works of this article (for both commercial and non-commercial purposes), subject to full attribution to the original publication and authors. The full terms of this license may be seen

at: http://creativecommons.org/licences/by/4.0/legalcode

Vol. 10(3) 2021, Pg. 809 - 821 


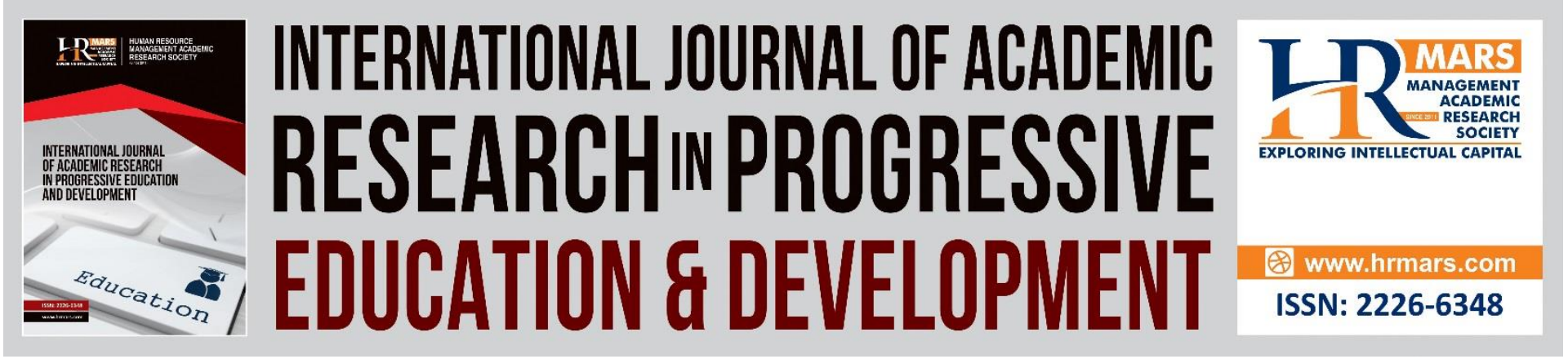

\title{
The Acceptance of Women as Academicians and Mothers When Working from Home (WFH) Becomes A Future Practice: A Preliminary Study
}

\author{
Nur Idayu Badrolhisam, Siti Norashikin Bashirun, Nurhafizah \\ Mohd Zolkapli, Nor Maslia Rasli Samudin \\ Faculty of Business and Management, Universiti Teknologi MARA, Melaka Malaysia
}

\begin{abstract}
With the COVID-19 pandemic hit the world today, higher education institutions need to change their teaching method from the physical classroom to the virtual. Some employees see this as an improvement opportunity, but some are not because WFH is never easy when they have a family. Women as academicians and mothers are perceived to carry it heavier because they must juggle work and family. The situation can add up to stressful events when managing classes online and children simultaneously at home. Demanding work and personal duty are challenging to balance. Hence, this preliminary study explores these women's needs, support systems and acceptance of converting physical office settings into WFH as a future practice. The given research follows a descriptive research design and quantitative approach to fulfill the study's principal objective. Quota sampling has been chosen in this study that comprises a sample size of 165 women academicians as mothers. These women academicians are married and single/divorced mothers with children below and above 18 years old. They are also working in Malaysian public universities regardless of academic positions and responsibilities. A structured and self-administered questionnaire-based survey was used for data collection from the participants. Based on the data collected, this research concludes that more than half of the respondents agree to have WFH as future practice with the capacity to WFH a few times a week.
\end{abstract}

Keywords: Acceptance Level, Mothers, Public Universities, Work from Home, Women Academicians

Introduction

Many women receive an equal chance in various employment sectors in today's world, including in the academic field. Then, when they got married, their focus is divided into family and career. Although women's participation in education line as the academicians are not new, they must choose between family, career advancement or have both simultaneously (Ismail, Rasdi, \& Wahat, 2005). They must also make choices that can help balance their career and family, such as sacrificing work achievement and cutting working hours for 
nonwork commitment (Philipsen, 2008). In any situation, it is hard for them to juggle with work-life-balance that can also contribute to emotional and mental instability.

Since we are currently facing the Covid-19 pandemic, the higher education system is forced to change its teaching method from face-to-face to online learning through Zoom and Google Meets (Darma et al., 2020). Astoundingly, today's pandemic is likely pushing the industrial revolution 4.0 (IR4.0) to be achieved faster where classes with the face-to-face pattern now become learning from home's norm (Darma et al., 2020). This talk of the town has been discussed for years as it is one of the IR4.0 outcomes. In Malaysia, this revolutionary is heavily promoted as part of revamping the higher education system. It encourages cyberphysical existence for teaching and learning, and all stakeholders can execute it at their own house (Halili, 2019; Ministry of Higher Education Malaysia, 2018).

Eventually, these add up to stressful events when managing classes online and children simultaneously at home. Women as mothers will be most likely to be affected by the situation. If they have not had someone to look after their children, they must care for their children alone while WFH. For instance, over $40 \%$ of female academics are responsible for their children's care, while $17 \%$ struggle to balance it with work (Kraft \& Simon, 2020). Similarly, a respondent from Couch, O'Sullivan, and Malatzky (2020) acknowledged that she is struggling to be available for her kids while WFH and becomes anxious about the memories her children may form on her as a mother during this pandemic. With these statements and results from many similar studies, this paper explored further the acceptance of women as academicians and mothers when WFH becomes the future workplace, especially in Malaysian public universities.

\section{The Challenge of Working from Home (WFH) During the Covid-19 Pandemic}

Jack Nilles promoted the idea of WFH in 1973 because of the international oil crisis that reflected on petrol consumption, heavy traffic, and long work commutes (Saludin, Karia \& Hassan, 2013). WFH refers to choosing to work from employees' homes or other locations rather than working at the office building and still getting paid (Reshma, Shailashree, \& Acharya, 2015). WFH is also described as working outside the typical workplace, connecting home and office (Rupietta \& Beckmann, 2016). Other terms that can be used are teleworking, telecommuting, working at home, and homeworking (Hassan \& Nuruddin, 2011). However, the term WFH will be used for the entire paper.

Then, the COVID-19 hit Malaysia in January 2020 through three imported Chinese nationals' cases to spread to the local community (Elengoe, 2020). With the increasing numbers of COVID-19, the Malaysian Government has to impose new guidelines on preventing it, including WFH. WFH setting is enforced after Malaysia decided to control the situation through the Movement Control Order (MCO). A third of Malaysians in both the private and public sectors must adhere to the rule (UNDP, 2020). Many public and private sectors recommend WFH as a social and physical distancing to avoid this pandemic. Hence, it becomes an essential alternative during the quarantine period. Additionally, a report shows that $59.2 \%$ of employees from the Malaysian education sector work at home in general (Lim, 2020).

This new setup is concurrent with the IR4.0 people have been talking about in the past few years. Although it is a surprise that an outbreak becomes one of the drivers in implementing IR4.0, it helps the education system open opportunities for creative and innovative thinking (Darma et al., 2020). This pandemic also shows the importance of training 
and updating plans for online teaching and learning as future preparation (García-González et al., 2020). Surprisingly, a study conducted in universities around Canada and Australia shows that their employees want to work from home even before the pandemic happened (Kutz, 2020).

Nevertheless, not everyone is happy with WFH, even though it provides a pleasant work setting (Kutz, 2020). The academicians face work stress and ineffective communication, and they are not willing to increase the work amount when WFH is compared to general and professional employees (Kutz, 2020). The Office of Corporate Affairs of Universiti Teknologi Malaysia also conducted a 2020 WFH survey that identifies $73 \%$ of their staff preferred working from the office (WFO), not WFH (cited in The Star, 2020). The survey concludes that they need to adjust the new arrangement while taking care of their children at home. The inefficient time dynamics of online teaching contribute to increasing workload in a particular situation like in conducting exams (García-González et al., 2020). Whatever the reasons mentioned above, the issues are discussed in general, including both women and men academicians. Both genders have been perceived to be impacted by the same benefits and problems when WFH as academicians. Therefore, the subsequent literature will focus specifically on women as academicians and mothers when WFH.

Several media outlets report women's challenges as mothers when WFH, which $40 \%$ must balance work and family (Tan, 2020). However, a survey conducted by United Nation Development (UNDP) Malaysia, Singapore, and Brunei Darussalam found that the quality of life (QOL) of those women are improving $31 \%$ and $59 \%$ of women say their productivity stay the same or improve as well (Tan, 2020). Nevertheless, the report is a generalization and is not the same in the higher education sector. Women academicians need to spend extra time teaching commitments and administrative works simultaneously when WFH (Kutz, 2020). When they have children, regardless of being married, divorced, or single, they are most likely to devote their time to household duties compared to men (Minello, 2020). These responsibilities affect women academicians' motivation and mental ability to juggle, especially with school-age children (Idris, 2011).

Flaherty (2020a) interviewed an associate professor from the University of California, Kim Yi Dionne, about her experiences when WFH. She stated that COVID-19 had affected women academicians' careers significantly because they must perform child-rearing and household duties. She also mentioned that while WFH, she must home-school her two kids aged 7 and 12 because the schools are closed. The effort to balance family and career options can lead to psychosocial risk like emotional dissonance and exhaustion (García-González et al., 2020). Concerning that, women's productivity dropped significantly, especially at the beginning of the COVID-19 outbreak (Flaherty, 2020b; Flaherty, 2020c). The journals' editors see a decreasing curve for solo-authored women, and this should raise concerns (Flaherty, 2006b). Moreover, the women's publishing rate compared to men's authorship in medical fields has also been drastically impacted by this outbreak (Gabster et al., 2020; Frederickson. 2020). This trend is consistent in other areas, too, like in economics, where the women authors' percentage drop from $21 \%$ (during non-COVID-19) to $12 \%$ (during COVID-19) (Amano-Patino et al., 2020).

With this drastic outcome, the publication rate data may stay the same or decrease, especially for academicians who are single women with children (Minello, 2020). Hence, WFH is too complicated to be standardized in a simple summary of the management as it does not provide solutions to these problems (Flaherty, 2020c; Kutz, 2020). Women are experiencing 
more occupational stress with various psychological symptoms (Melhinsh, 1998). The probability of getting affected by mental and emotional challenges is also higher than men. This statement is supported by many studies that expressed those women get more stress than men often (Arroba \& James, 2002). Therefore, converting the office setting to WFH can significantly pull women if they do not address it sooner and appropriately. Hence, this study answered the two research objectives:

1. What are the needs required from women academicians as mothers if WFH becomes a future practice?

2. Will women academicians as mothers accept the opportunity when WFH becomes a future practice?

\section{Methodology}

The given research followed a descriptive research design and quantitative research approach to fulfill the study's primary objective. The participants' criterion was women academicians who are married and single/divorced mothers with children below and above 18 years old. They are also working in Malaysian public universities regardless of academic positions and responsibilities. The primary method of data collection was used in this research study. Structured, close-ended questions and a self-administered questionnaire-based survey was carried out for the data collection process. The non-probability technique with quota sampling was chosen in this study. Nevertheless, the study could not identify the population size of women academicians as mothers in Malaysian public universities. According to LaMorte (2016), selecting representative of the target population is possible when the probability of the sample is unknown in certain situations. Using quota sampling for unknown population size (LaMorte, 2016), the study estimates the sample size in Table 1: 
INTERNATIONAL JOURNAL OF ACADEMIC RESEARCH IN PROGRESSIVE EDUCATION AND

DEVELOPMENT

Vol. 10, No. 3, 2021, E-ISSN: 2226-6348 @ 2021 HRMARS

Table 1: Quota Sampling According to LaMorte (2016)

\begin{tabular}{|l|l|l|}
\hline $\begin{array}{l}\text { Women academicians as } \\
\text { mothers in Malaysian public } \\
\text { universities }\end{array}$ & Distribution in population & $\begin{array}{l}\text { Quota to Achieve } \\
\mathbf{n}=\mathbf{3 6 0}\end{array}$ \\
\hline UiTM & $5.56 \%$ & $\mathrm{n}=20$ \\
\hline IIUM & $5.56 \%$ & $\mathrm{n}=20$ \\
\hline USIM & $5.56 \%$ & $\mathrm{n}=20$ \\
\hline UNIMAS & $5.56 \%$ & $\mathrm{n}=20$ \\
\hline UTeM & $5.56 \%$ & $\mathrm{n}=20$ \\
\hline UTHM & $5.56 \%$ & $\mathrm{n}=20$ \\
\hline UPSI & $5.56 \%$ & $\mathrm{n}=20$ \\
\hline UM, & $5.56 \%$ & $\mathrm{n}=20$ \\
\hline UniSZA & $5.56 \%$ & $\mathrm{n}=20$ \\
\hline UTM & $5.56 \%$ & $\mathrm{n}=20$ \\
\hline UMS & $5.56 \%$ & $\mathrm{n}=20$ \\
\hline UKM & $5.56 \%$ & $\mathrm{n}=20$ \\
\hline UUM & $5.56 \%$ & $\mathrm{n}=20$ \\
\hline UniMAP & $5.56 \%$ & $\mathrm{n}=20$ \\
\hline USM & $5.56 \%$ & $\mathrm{n}=20$ \\
\hline UMP & $5.56 \%$ & $\mathrm{n}=20$ \\
\hline UMT & $5.56 \%$ & $\mathrm{n}=20$ \\
\hline UMK & $5.56 \%$ & $\mathrm{n}=20$ \\
\hline & & \\
\hline
\end{tabular}

However, the study found several limitations during the data collection process. The survey was sent to 360 respondents in twenty Malaysian public universities. Out of 360 , there were 176 respondents who answered the survey but only 165 managed to complete it. The study was unable to identify any technical issue or error, whether it was from the survey or from the respondents' capacity since the study applied the confidentiality rule. Therefore, it is impossible to keep track of who had gone through the survey but did not complete it. The survey was also sent through email using an online form to the participants due to Movement Control Order 2.0 and 3.0 (MCO) enforced by the Malaysian Government. Hence, the researchers could not move freely to each public university during this process. In addition, the slow response with a limited deadline, the study unable to achieve the targeted sample size mentioned above. Thus, this study decided to take these 165 completed responses and analyzed them.

\section{Findings and Discussions \\ Descriptive Analysis}

Table 2 shows the demographic background of 165 women academicians working in Malaysian public universities (total $=20$ ). Most respondents are mothers with spouses or partners ( $n=156,94.5 \%)$, and most of them have more than one child ( $n=136,82.4 \%)$. In addition, the margin of having children age below 18 years old is more significant than above 18. Other than that, many have been working in the higher education sector for more than ten years $(n=97,58.8 \%)$. There is also a significant range of experience WFH before the COVID19 pandemic where $n=113$ (68.5\%) respondents never WFH before. 
INTERNATIONAL JOURNAL OF ACADEMIC RESEARCH IN PROGRESSIVE EDUCATION AND

DEVELOPMENT

Vol. 10, No. 3, 2021, E-ISSN: 2226-6348 @ 2021 HRMARS

Table 2. Demographic Background of Women Academicians Working in Malaysian Public Universities

\begin{tabular}{|c|c|c|c|}
\hline Variables & Category & $\begin{array}{l}\text { Frequency } \\
\text { (n) }\end{array}$ & $\begin{array}{l}\text { Percentage } \\
\text { (\%) }\end{array}$ \\
\hline \multirow{3}{*}{ Marital status } & $\begin{array}{l}\text { A mother with a } \\
\text { spouse/partner }\end{array}$ & 156 & 94.5 \\
\hline & $\begin{array}{l}\text { A co-parenting } \\
\text { mother }\end{array}$ & 3 & 1.8 \\
\hline & A single mother & 6 & 3.6 \\
\hline \multirow[b]{2}{*}{ Number of children } & One child & 29 & 17.6 \\
\hline & $\begin{array}{l}\text { More than one } \\
\text { child }\end{array}$ & 136 & 82.4 \\
\hline \multirow{4}{*}{ Children age } & $\begin{array}{l}\text { Age below six } \\
\text { years old }\end{array}$ & 91 & 55.2 \\
\hline & $\begin{array}{l}\text { Age } 7 \text { to } 12 \text { years } \\
\text { old }\end{array}$ & 93 & 56.4 \\
\hline & $\begin{array}{l}\text { Age } 13 \text { to } 17 \text { years } \\
\text { old }\end{array}$ & 56 & 33.9 \\
\hline & $\begin{array}{l}\text { Age } 18 \text { years and } \\
\text { above }\end{array}$ & 39 & 23.6 \\
\hline \multirow{2}{*}{ Holding administrative position } & \begin{tabular}{|l|l|} 
Yes \\
\end{tabular} & 57 & 34.5 \\
\hline & No & 108 & 65.5 \\
\hline \multirow{4}{*}{ Working experience in higher education } & 1 to 3 years & 13 & 7.9 \\
\hline & 3 to 5 years & 15 & 9.1 \\
\hline & 5 to 10 years & 40 & 24.2 \\
\hline & $\begin{array}{l}\text { More than ten } \\
\text { years }\end{array}$ & 97 & 58.8 \\
\hline \multirow{2}{*}{ WFH experience before the COVID-19 } & Yes & 52 & 31.5 \\
\hline & No & 113 & 68.5 \\
\hline
\end{tabular}

Next, based on Table 3, we observe the amount of support and trust the respondents perceive they receive from the university management when WFH. In a study by Chung, Seo, Forbes, and Birkett (2020), most United Kingdom (UK) employees felt their management supported WFH before the COVID-19 lockdown (50\%), and this increased considerably during the lockdown, with $90 \%$ indicating their bosses were encouraging of WFH. The finding of our study is similar to Chung et al. (2020), in which our respondents feel the support and trust from the management $(n=113,68.5 \%)$ when Malaysia has its first to third MCO since March 2020 (Shankar, 2021). 
INTERNATIONAL JOURNAL OF ACADEMIC RESEARCH IN PROGRESSIVE EDUCATION AND

DEVELOPMENT

Vol. 10, No. 3, 2021, E-ISSN: 2226-6348 @ 2021 HRMARS

Table 3. Support and Trust from the Management

\begin{tabular}{|l|l|l|l|}
\hline Variable & Response & $\begin{array}{l}\text { Frequency } \\
(\mathrm{n})\end{array}$ & $\begin{array}{l}\text { Percentage } \\
(\%)\end{array}$ \\
\hline \multirow{2}{*}{ Receive support and trust from the management } & Yes & 113 & 68.5 \\
\cline { 2 - 4 } & No & 14 & 8.5 \\
\cline { 2 - 4 } & Maybe & 38 & 23.0 \\
\hline
\end{tabular}

The exploration presented in this study is also divided into major parts in Table 4 and Table 5. The options for these women academicians require or need if WFH is a future practice are illustrated in Table 4. While Table 5 exemplified their acceptance level if the universities want to implement WFH as a future practice. The findings demonstrated in Table 4 are the ranking of options required by these women if the university management wants to transform WFO to WFH in the future. The highest ranking is the concern of salary and paycheck (mean=4.85) and the lowest is having option to wear comfortable clothes during formal meetings or online classes with the students (mean=3.64). One of the drawbacks when WFH is the fear of getting the salaries and wages cut (Lupu, 2017) and in this study the respondents feel like the salary's components should be maintained in the new work environment. According to Thorstensson (2020), maintaining or paying higher wages when employees WFH can improve employees' productivity as it helps employees to work longer hours and focus on work more without having to commute to the office. In addition, since WFH may reduce organizations' cost saving, it may help to reflect into increasing employees' salaries as well (Hill, Miller, Weiner, \& Colihan, 1998).

Subsequently, the second highest ranking is for the requirement for the organizations to trust the capabilities of the employees to perform job when WFH (mean=4.81). The WFH trust issues frequently rise to the foreground of workplace debates (International Labour Organization, 2020). The trust issue happens because the management no longer has the typical command and control managerial style since there is an absence of face-to-face interaction (International Labour Organization, 2020). Thus, Kniffin et al. (2021) suggest that organizations should implement and encourage trust-building procedures while also considering the costs of enhanced monitoring when employees WFH. Furthermore, trust is built on a task-based relationship, in which people will perform reliably, quickly and consistently if they commit to it (Kirkman et al., 2003). 
INTERNATIONAL JOURNAL OF ACADEMIC RESEARCH IN PROGRESSIVE EDUCATION AND

DEVELOPMENT

Vol. 10, No. 3, 2021, E-ISSN: 2226-6348 @ 2021 HRMARS

Table 4. Options Required if WFH Becomes a Future Practice

\begin{tabular}{|c|c|c|c|}
\hline Variables & Ranking & Mean & $\begin{array}{l}\text { Question } \\
\text { Number }\end{array}$ \\
\hline $\begin{array}{l}\text { The paycheck and salary should not be deducted } \\
\text { if choosing to WFH instead of WFO }\end{array}$ & 1 & 4.85 & 21 \\
\hline $\begin{array}{l}\text { The university should trust my capabilities to get } \\
\text { the job done if I choose to WFH instead of WFO }\end{array}$ & 2 & 4.81 & 23 \\
\hline $\begin{array}{l}\text { The opportunity to get promoted should be } \\
\text { decreased if I choose to WFH instead of WFO }\end{array}$ & 3 & 4.79 & 22 \\
\hline $\begin{array}{l}\text { There should be an option to have flexible time } \\
\text { to handle personal responsibilities }\end{array}$ & 4 & 4.73 & 12 \\
\hline $\begin{array}{l}\text { There should be an option to be listened by the } \\
\text { university regarding stress and emotional } \\
\text { burden }\end{array}$ & 5 & 4.64 & 19 \\
\hline $\begin{array}{l}\text { The university should do performance } \\
\text { evaluation fairly but flexibly according to } \\
\text { employees' expertise when WFH }\end{array}$ & 5 & 4.64 & 24 \\
\hline $\begin{array}{l}\text { There should be an option to organize job task } \\
\text { interdependently }\end{array}$ & 6 & 4.62 & 14 \\
\hline $\begin{array}{l}\text { There should be an option to create own goals } \\
\text { independently }\end{array}$ & 7 & 4.54 & 13 \\
\hline $\begin{array}{l}\text { There should be an option to conduct online } \\
\text { classes with the students according to own } \\
\text { competencies and facilities at hand }\end{array}$ & 8 & 4.52 & 16 \\
\hline $\begin{array}{l}\text { There should be an option to decide with work } \\
\text { engagement and commitment independently }\end{array}$ & 9 & 4.33 & 15 \\
\hline $\begin{array}{l}\text { There should be an option to choose clock in and } \\
\text { out as long it meets the university's criteria }\end{array}$ & 10 & 4.20 & 11 \\
\hline $\begin{array}{l}\text { There should be an option to enroll in a wellness } \\
\text { program provided by the university }\end{array}$ & 11 & 4.18 & 20 \\
\hline $\begin{array}{l}\text { There should be an option to limit unnecessary } \\
\text { interactions with any university's stakeholder }\end{array}$ & 12 & 4.02 & 17 \\
\hline $\begin{array}{l}\text { There should be an option to wear comfortable } \\
\text { clothes during formal meetings or classes }\end{array}$ & 13 & 3.64 & 18 \\
\hline
\end{tabular}

An interesting acceptance level emerged when examining the result shows in Table 5. The table reveals that even though there are high percentage of extremely agree $(n=73$, $44.2 \%)$ and agree $(n=44,26.7 \%)$ to have WFH as a future practice, the amount who does not agree at all, disagree and undecided about it are also considered important when total up. We assume that the reasons almost half the respondents in this study does not agree or undecided to accept WFH as a future practice because WFH is connected to lengthy working hours. There are similar data by Dockery \& Bawa (2014) that suggest WFH can make employees feel violated in non-work life because they have to work longer in home. Moreover, International Labour Organization (2021) supports that working long hours when WFH can affect the ability to socialize with other people and there is also a potential for job 
advancements that come from losing out on organizational politics. Hence, the ability to WFH is fully reliant on the existence of employees' children at home, as well as the availability of a comfortable workspace, a calm atmosphere, and reliable internet access (Shareena \& Shahid, 2020).

Table 5. Acceptance Level When WFH Becomes a Future Practice

\begin{tabular}{|l|l|l|}
\hline $\begin{array}{l}\text { Overall, I agree if the higher education sector decides to } \\
\text { make WFH becomes a future practice }\end{array}$ & $\begin{array}{l}\text { Frequency } \\
(\mathrm{n})\end{array}$ & $\begin{array}{l}\text { Percentage } \\
(\%)\end{array}$ \\
\hline Not agree at all & 11 & 6.7 \\
\hline Disagree & 11 & 6.7 \\
\hline Undecided & 26 & 15.8 \\
\hline Agree & 44 & 26.7 \\
\hline Extremely agree & 73 & 44.2 \\
\hline
\end{tabular}

Finally, the majority of respondents feel that they can see themselves WFH in the future a few times a week $(n=99,60 \%)$ as shown in Table 6 . A survey conducted in United States by International Labour Organization (2020) shows that nearly half of the 1,200 respondents are interested to continue WFH, and their companies mostly (45\%) are looking forward to considering this method in the future. A respondent in UNDP Report (2020) also acknowledges that two to three days of WFH seems ideal and another respond that organizations should additionally allow employees to choose how often they want to work from home and whether or not they want to come into the office. Thus, organizations in Malaysia should deliberate on this since our study also show more than half respondents agree on WFH becomes a future practice with the potential of working a few times a week at home.

Table 6. The Frequency of Seeing One-Self WFH as future practice

\begin{tabular}{|l|l|l|}
\hline Items & $\begin{array}{l}\text { Frequency } \\
(\mathrm{n})\end{array}$ & $\begin{array}{l}\text { Percentage } \\
(\%)\end{array}$ \\
\hline Once a week & 20 & 12.1 \\
\hline A few times a week & 99 & 60.0 \\
\hline Always & 46 & 27.9 \\
\hline
\end{tabular}

\section{Conclusion}

The main conclusion of this work is drawn that WFH may become a future practice with the options to WFH a few times a week. WFH can be a more productive work environment than the typical office, which might improve work-life quality. The practice may affect performance appraisal and employees' job satisfaction; hence, a better guideline is needed to regulate and implement WFH effectively. The work-life balance after the pandemic may also become visible if WFH is not a mandatory mandate but a flexible option.

The study identified several limitations that require further research on it since it was only a preliminary study. First, this study was not longitudinal research; therefore, it might not represent the whole population of women academicians as mothers in Malaysia. In addition, since the Malaysian Government is currently enforcing MCO 3.0 we were unable to retrieve the exact sample size of the respondents working in 20 Malaysian public universities. As the 
interaction was online (i.e., email), it was difficult to get the private and confidential demographic information from each university since it is restricted. Therefore, it is suggested for future research to find a sufficient sample size after MCO 3.0 is lifted and collaborate with the universities' management to get the data.

Second, the study found that most reviews are from Western perspectives; thus, there may be some differences in WFH cultures. Although the number of WFH studies is increasing in the Malaysian context, we would like to recommend future research to explore more in this area and compare the employees' perspective in both private and public sectors and cultural differences between countries. Lastly, this study was a descriptive study with no correlation, impact, or significant contribution that can further develop into a framework or approach. Hence, we want to propose the future research to use other research designs to contribute more to the body of knowledge in terms of new profound research frameworks (e.g., Industrial Revolution area or Sustainable Development Goals area). Moreover, future research can also include male's respondents to get insightful findings on how men and women experience and perceive the WFH situation.

\section{Acknowledgement}

The authors would like to express appreciation to Universiti Teknologi MARA Research Ethics Committee for approving the project (REC/05/2021 (MR/298)) for the university's ongoing research outcomes. Also, the deepest gratitude to the respondents who participated and contributed to the findings of this study willingly.

\section{Corresponding Author}

Nur Idayu Badrolhisam

Faculty of Business and Management, Universiti Teknologi MARA Cawangan Selangor, Malaysia

Email: nur_idayu24@uitm.edu.my

\section{References}

Amano-Patiño, N., Faraglia, E., Giannitsarou, C., \& Hasna, Z. (2020). Who is doing new research in the time of COVID-19? Not the female economists. Publishing and Measuring Success in Economics. London: Centre for Economic Policy Research. Recuperado de: https://voxeu.org/article/who-doing-new-research-time-covid-19not-female-economists.

Chung, H., Seo, H., Forbes, S., \& Birket, H. (2020). Working from home during the COVID-19 lockdown: Changing preferences and the future of work. University of Kent and University of Birmingham.

Couch, D. L., O'Sullivan, B., \& Malatzky, C. (2020). What COVID-19 could mean for the future of "work from home": The provocations of three women in the academy. Gender, Work \& Organization, 1-10.

Darma, D. C., Ilmi, Z., Darma, S., \& Syaharuddin, Y. (2020). COVID-19 and its Impact on Education: Challenges from Industry 4.0. AQUADEMIA, 4(2), 1-4.

Dockery, A. M., \& Bawa, S. (2014). Is Working from Home Good Work or Bad Work? Evidence from Australian Employees. Australian Journal Of Labour Economics, 17(2), 163-190.

Elengoe, A. (2020). COVID-19 Outbreak in Malaysia. Osong Public Health and Research Perspectives, 93-100. 
Fairbairn, W., \& Kessler, A. (2015). Practical Advice for Selecting Sample Sizes. The Donor Committee for Enterprise Development, Retrieved from https://www.enterprisedevelopment.org/wpcontent/uploads/Practical_advice_for_selecting_sample_sizes_ May2015.pdf

Flaherty, C. (2020a). Faculty Home Work. Inside Higher Ed, Retrieved from https://www.insidehighered.com/news/2020/03/24/working-home-during-covid19-proves-challenging-faculty-members

Flaherty, C. (2020b). No Room of One's Own. Inside Higher Ed, Retrieved from https://www.insidehighered.com/news/2020/04/21/early-journal-submission-datasuggest-covid-19-tanking-womens-research-productivity

Flaherty, C. (2020c). Something's Got to Give. Inside Higher Ed, Retrieved from https://www.insidehighered.com/news/2020/08/20/womens-journal-submissionrates-continue-fall

Gabster, B. P., van Daalen, K., Dhatt, R., \& Barry, M. (2020). Challenges for the female academic during the COVID-19 pandemic. Lancet, 395, 1968-1970.

García-González, M. A., Torrano, F., \& García-González, G. (2020). Analysis of Stress Factors for Female Professors at Online Universities. International Journal of Environmental Research and Public Health, 17, 1-13.

Halili, S. H. (2019). Technological Advancements In Education 4.0. The Online Journal of Distance Education and e-Learning, 7(1), 63-69.

Hassan, H., \& Nuruddin, A. R. (2011). Working From Home Concept for Quantity Surveying Employment. The Quantity Surveying International Convention 2011. Penang, Malaysia

Hill, E. J., Miller, B. C., Weiner, S. P., \& Colihan, J. (1998). Influences of the virtual office on aspects of work and work/life balance. Personnel Psychology, 51, 1.

Idris, M. K. (2011). Over Time Effects of Role Stress on Psychological Strain among Malaysian Public University Academics. International Journal of Business and Social Science, 2(9), 154-161.

International Labour Organization. (2020). An employers' guide on working from home in response to the outbreak of COVID-19. Geneva: International Labour Organization.

International Labour Organization. (2021). Working from home From invisibility to decent work. Geneva: International Labour Organization.

Ismail, M., Rasdi, R. M., \& Wahat, N. W. A. (2005). High-flyer women academicians: factors contributing to success. Women in Management Review.

Kirkman, B. L., Rosen, B., Gibson, C. B., Tesluk, P. E., \& McPherson, S. O. (2002). Five challenges to virtual team success: Lessons from Sabre, Inc. Academy of Management Perspectives, 16(3), 67-79.

Kniffin, K. M., Narayanan, J., Anseel, F., Antonakis, J., Ashford, S. P., Bakker, A. B., Bamberger, P., Bapuji, H., Bhave, D. P., Choi, V. K., Creary, S. J., Demerouti, E., Flynn, F. J., Gelfand, M. J., Greer, L. L., Johns, G., Kesebir, S., Klein, P. G., Lee, S. Y., Vugt, M. V. (2021). COVID19 and the workplace: Implications, issues, and insights for future research and action. American Psychologist, 76(1), 63-77. https://doi.org/10.1037/amp0000716

Kutz, C. (2020). Working from home during COVID-19: What do employees really want? The Conversation, Retrieved from https://theconversation.com/working-from-homeduring-covid-19-what-do-employees-really-want-148424 
LaMorte, W. W. (2016). The role of probability. Retrieved February 17, 2021, from https://sphweb.bumc.bu.edu/otlt/MPHModules/BS/BS704_Probability/BS704_Prob ability2.html

Lim, L. L. (2020). The socioeconomic impacts of COVID-19 in Malaysia: Policy review and guidance for protecting the most vulnerable and supporting enterprises. International Labour Organization.

Lupu, V. L. (2017). Teleworking and Its Benefits on Work-Life Balance. International Multidisciplinary Scientific Conference on Social Sciences \& Arts SGEM, (p. 693). Albena.

Melhinsh, A. (1998). Executive Health. London: Business Books.

Minello, A. (2020). The pandemic and the female academic. Nature Research, Retrieved from https://www.nature.com/articles/d41586-020-01135-9

Ministry of Higher Education Malaysia. (2018). Framing Malaysian Higher Education 4.0:

Future-Proof Talents. Putrajaya, Malaysia: Department of Higher Education, Ministry of Higher Education Malaysia.

Philipsen, M. I. (2008). Challenges of the Faculty Career for Women. San Francisco: JosseyBass.

Reshma, P. S., Shailashree, V. T., \& Acharya, S. (2015). An Empirical Study On Working From Home: A Popular E-Business Model. International Journal of Advance and Innovative Research, $2(2(\mathrm{I})), 12-18$.

Rupietta, K., \& Beckmann, M. (2016). Working from home: What is the effect on employees' effort? WWZ Working Paper. Basel, Switzerland: University of Basel.

Saludin, N. A., Karia, N., \& Hassan, H. (2013). Working from Home (WFH): Is Malaysia Ready for Digital Society? Entrepreneurship Vision 2020: Innovation, Development Sustainability, and Economic Growth Proceedings of the 20th International Business Information Management Association Conference (pp. 981-989). Kuala Lumpur: International Business Information Management Association .

Shankar, A. S. (2021). Total lockdown like MCO 1.0 should be avoided, says Amcham. The Edge Markets, Retrieved from https://www.theedgemarkets.com/article/total-lockdownmco-10-should-be-avoided-says-amcham

Shareena, P., \& Shahid, M. (2020). Work from home during COVID-19: Employees perception and experiences. Global Journal for Research Analysis, 9(5), 7-10.

Tan, D. (13 August, 2020). Working on Work from Home, From Home. United Nations Development Programme Malaysia, Singapore \& Brunei Darussalam, Retrieved from https://www.my.undp.org/content/malaysia/en/home/blog/2020/working-on-workfrom-home--from-home.html

Thorstensson, E. (2020). The Influence of Working from Home on Employees' Productivity: Comparative document analysis between the years 2000 and 2019-2020. Karlstad, Sweeden: Karlstad University.

UNDP. (2020). How We Worked from Home. United Nations Development Programme. Putrajaya: UNDP Accelerator Lab Malaysia. 